\title{
EXPLOSIVE RANGE EXPANSION OF EULOPHIA GRAMINEA (ORCHIDACEAE) IN PUERTO RICO AND THE WEST INDIES
}

\author{
JAMES D. ACKERMAN ${ }^{1-2} \&$ Normandie GonZÁLEZ-ORELLANA ${ }^{1}$
}

\author{
${ }^{1}$ Department of Biology, University of Puerto Rico, 17 Avenida Universidad Suite 1701, San Juan, \\ Puerto Rico, 00925-2537, U.S.A. \\ ${ }^{2}$ Author for correspondence: ackerman.upr@gmail.com
}

\begin{abstract}
Aвstract. Eulophia graminea Lindley (Orchidaceae), a native orchid of tropical and subtropical Asia, was first reported in the Western Hemisphere from populations in Miami, Florida, U.S.A. where it spread rapidly through the southern part of the state. Here we report the first record of this species for Puerto Rico and sightings in the Bahamas and Cuba, reflecting the rapid spread seen in southern Florida (U.S.A).

Resumen. Eulophia graminea Lindley (Orchidaceae), una orquídea nativa de Asia tropical y subtropical se informó por primera vez en el hemisferio occidental en poblaciones de Miami, Florida, EE. UU., donde se extendió rápidamente por la parte sur del estado. Aquí informamos el primer registro de esta especie para Puerto Rico y también avistamientos en las Bahamas y Cuba, lo que refleja la rápida propagación observada en sur de Florida (EE. UU.).
\end{abstract}

Key Words/Palabras clave: Caribbean, Caribe, Chinese Crown Orchid, especie invasora, invasive species, range expansion, rango de distribución, Grass-Leaved Eulophia, orchid, Orquídea Corona China

Introduction. Native orchid species do not often exhibit rapid range expansion (e.g., Oncidium poikilostalix (Kraenzl.) M.W.Chase \& N.H.Williams, García-González et al. 2013; Microtis media R.Br., Bonnardeaux et al. 2007), but the incidence of nonindigenous orchids invading new regions has become more noticeable (Stern 1988, Ackerman 2007, 2017). Herein we report the continuation of a rapid range expansion by the non-indigenous species Eulophia graminea Lindley (Orchidaceae), a terrestrial orchid commonly known as the Chinese Crown Orchid or Grass-Leaved Eulophia. Eulophia graminea is native to Sri Lanka, India, Nepal, Pakistan, Kashmir, Myanmar, Thailand, Laos, Vietnam, Malaysia, Indonesia, Philippines, northward to subtropical China, Taiwan, and the Ryukyu Islands. Within its native range, it has considerable ecological amplitude growing in open areas, grasslands, beaches, lawns, roadsides, shrubby habitats, and in open forests at elevations from sea level to $1200 \mathrm{~m}$ (Pemberton et al. 2008, Ang et al. 2011, Orchid Species 2021).

In the last two decades, E. graminea has become naturalized in Australia, South Africa, and Florida, U.S.A. (Macrae 2002, O’Conner et al. 2006, Pember- ton et al. 2008, PIER 2021). In just a few years, reports of E. graminea in southern Florida increased from five populations in Miami-Dade County in 2007 to 67 locations in seven counties in 2010 (Pemberton 2013). The orchid is now known from 18 Florida counties (Wunderlin et al. 2021) and has been discovered in the Bahamas on at least three different islands (Sandy Point, Abaco; near Grand Bahama airport, Grand Bahama; Governor's Harbour, Eleuthera; Michael Vincent and Ethan Freid, personal communications with JDA 2010, 2014, 2015, photos!), and in at least three provinces in Cuba (Camagüey, Oscar Loyola Hernández, personal communication with JDA 2018, photos! Santa Clara, Quemado de Güines, José Luis Gómez-Hechavarría, iNaturalist.org/photos/118262829!; Pinar del Río, José Lazaro Bocourt, personal communication with JDA 2020, photos!) (Fig.1A).

Eulophia graminea has strong colonizing abilities. In its native range, the grass-like plants occupy similar open, disturbed habitats as do Spathoglottis plicata Blume and Arundina graminifolia (D.Don) Hochr., both of which are also invaders on tropical islands and continental regions (Ackerman 2007, Ang et al. 2011, Kolanowska \& Konowalik 2014). In native and 


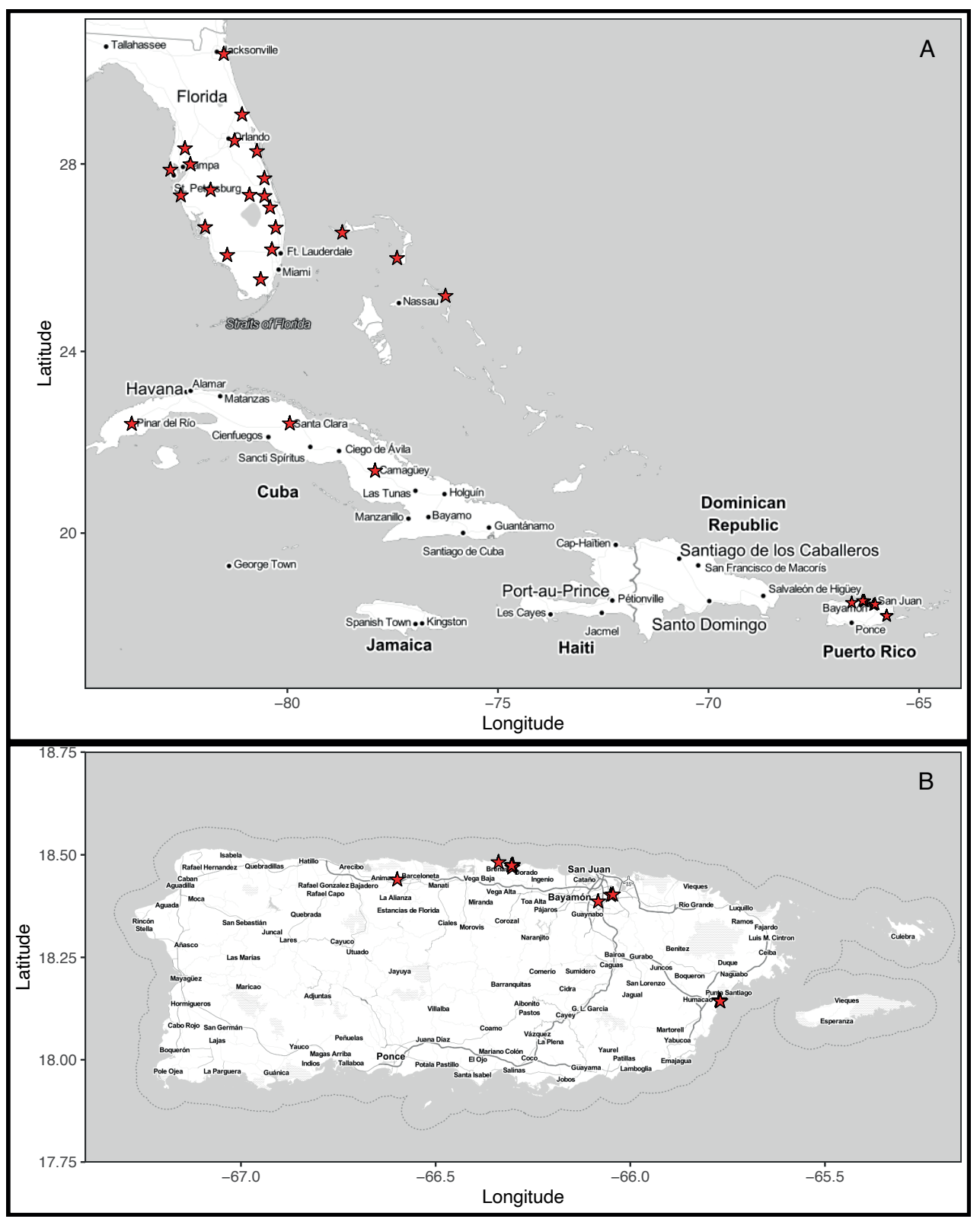

Figure 1. Distribution of Eulophia graminea in the Western Hemisphere. A. Distribution in Florida and the West Indies. We placed the stars in the center of the counties (Florida), islands (Bahamas), and provinces (Cuba) where E. graminea has been reported. B. Distribution within Puerto Rico. Placement of stars is based on coordinates of each locality. Maps were created with ggplot2, ggmap, and ggstar in R Studio Team (2021).

invaded habitats, E. graminea can occur in a variety of substrates from beach sands to garden wood-chip mulch, probably exploiting a wide variety of mycorrhizal fungi, including wood decaying fungi. Flowers sometimes self-pollinate and may bloom within one year of sowing in vitro (Chang et al., 2010). Pemberton et al. (2008) determined in Florida (U.S.A.), via bagging experiment, that E. graminea is indeed at least partially self-compatible. They estimated fruit set as $4.5 \%$ and $9.2 \%$ in two different populations in 
southern Florida. Despite their assertions of pollinator-dependency, they failed to observe any pollinator visits. While we have not made a concerted effort to observe pollination, we also have failed to see any visits during our casual visits to Puerto Rico populations. We found that the spurs contain a small amount of nectar $(0.5 \mu \mathrm{l})$ making the low fruit set unusual for species offering a pollinator reward (Tremblay et al. 2005). When we collected inflorescences for vouchers and to check for nectar, we noticed that the pollinaria were easily dislodged. It remains to be seen whether or not autogamy involves natural perturbations, such as wind and rain, to dislodge the pollinia and contact the stigma as occurs in a few other orchids (Catling 1980, Fan et al. 2012, Suetsugu 2019), including the congeneric E. maculata (González-Díaz \& Ackerman 1988, as Oeceoclades maculata (Lindley) Lindley; see discussion below).

Eulophia graminea was first discovered in Puerto Rico in 2018. Adolfo Rodríguez Velázquez, a graduate student at the University of Puerto Rico, Río Piedras, found a single plant in disturbed, secondary vegetation in the limestone region "mogotes" on the northern side of the island. While only one plant was discovered, there may have been more because they are difficult to detect since the leaves are fugacious, withering before the onset of anthesis. Two years later, Dr. Tamara Heartsill Scalley sent JDA photos of this orchid growing in thick Bermuda grass under street trees in the city of San Juan. At this site, we found ten inflorescences, averaging 12 flowers apiece. Half the inflorescences showed no signs of developing fruit. From the remainder, we estimated the average fruit set for the population was $10.6 \%$. Since then, we have discovered a population in the municipalities of Dorado (Dorado Beach Hotel; Steve Maldonado Silvestrini and Christian Torres Santana, personal communications with JDA, 2020); Vega Alta (Sabana, Cerro Gordo, Ritirene observer, iNaturalist; accessed 21 April 2021); Humacao and two populations observed by us in San Juan on campus of the University of Puerto Rico, Río Piedras (Fig. 1B). The march of the species may become as fast as other naturalized orchids of Puerto Rico: Eulophia maculata (Lindl.) Reichb.f. (synonym: Oeceoclades maculata (Lindl.) Lindl.), Spathoglottis plicata, Dendrobium crumenatum Sw., and Arundina graminifolia (Ackerman 2007, Falcón et al. 2017, Foster \& Ackerman 2021).
Should we be concerned that E. graminea is spreading rapidly? While invasive species are usually tagged in a negative fashion (Larson 2005), the spread of some non-indigenous species have little or no negative consequences, sometimes can be beneficial, and effects are often context dependent (Daehler 2003). Concerning orchids, roots of non-indigenous Vanda tricolor Lindl. were seen "nearly smothering" a native host tree (Oppenheimer 2006). Epipactis helleborine (L.) Crantz is perhaps the first non-indigenous orchid to invade North America, where it is considered a troublesome weed in lawns and gardens in some urban areas (Squirrell et al. 2001). Donald Dod (1986) reported that E. maculata in the Dominican Republic was an agricultural pest in sugar cane fields requiring heavy farm machinery to eradicate them. Several studies of invasive orchids have focused on whether or not they had negative consequences on native orchids; the results are usually equivocal (e.g., Bonnardeaux et al. 2007, Cohen \& Ackerman 2009), but significant negative results can be subtle through various means, including apparent competition (Recart et al. 2013). While E. graminea can form dense monocultures (UF/ IFAS 2021), we do not expect the invasion of E. graminea to be ecologically harmful on a large scale. Nevertheless, it is wise to monitor populations just as it would be for any non-indigenous species.

VOUCHers: Puerto Rico. Municipality of Arecibo: Barrio Garrochales, Rd 682, Cambalache State Forest, $18.439461^{\circ},-66.598530^{\circ}$, moist limestone forest vegetation, elev. 100 m, Dec 2018, A. Rodríguez Velázquez s.n. (UPRRP). Municipality of San Juan: Río Piedras, Urbanization San Francisco, Avenue de Diego near intersection with Calle Verbena, $18.386124^{\circ}$, $-66.082531^{\circ}$, elev. $26 \mathrm{~m}$, growing under street trees of Calophyllum antillanum Britton, "Maria", in thick untended Bermuda grass (Cynodon dactylon (Linnaeus) Persoon 16 Jul 2020, J. D. Ackerman 6080 (UPRRP). Loc. cit., 15 Jul 2020, T. Heartsill s.n. (UPRRP). Río Piedras, University of Puerto Rico, in front of the Julio García Díaz building, $18.401728^{\circ}$, -66.049554 , elev. 28 m, 16 Apr 2021 N. González-Orellana s.n. (UPRRP). Municipality of Humacao: Reserva Natural Efraín Archilla Díez, Camino de los Helechos, $18.145035^{\circ},-65.771287^{\circ}$, elev. near sea level, $23 \mathrm{Feb}$ 2021, N. González-Orellana s.n. (UPRRP). 


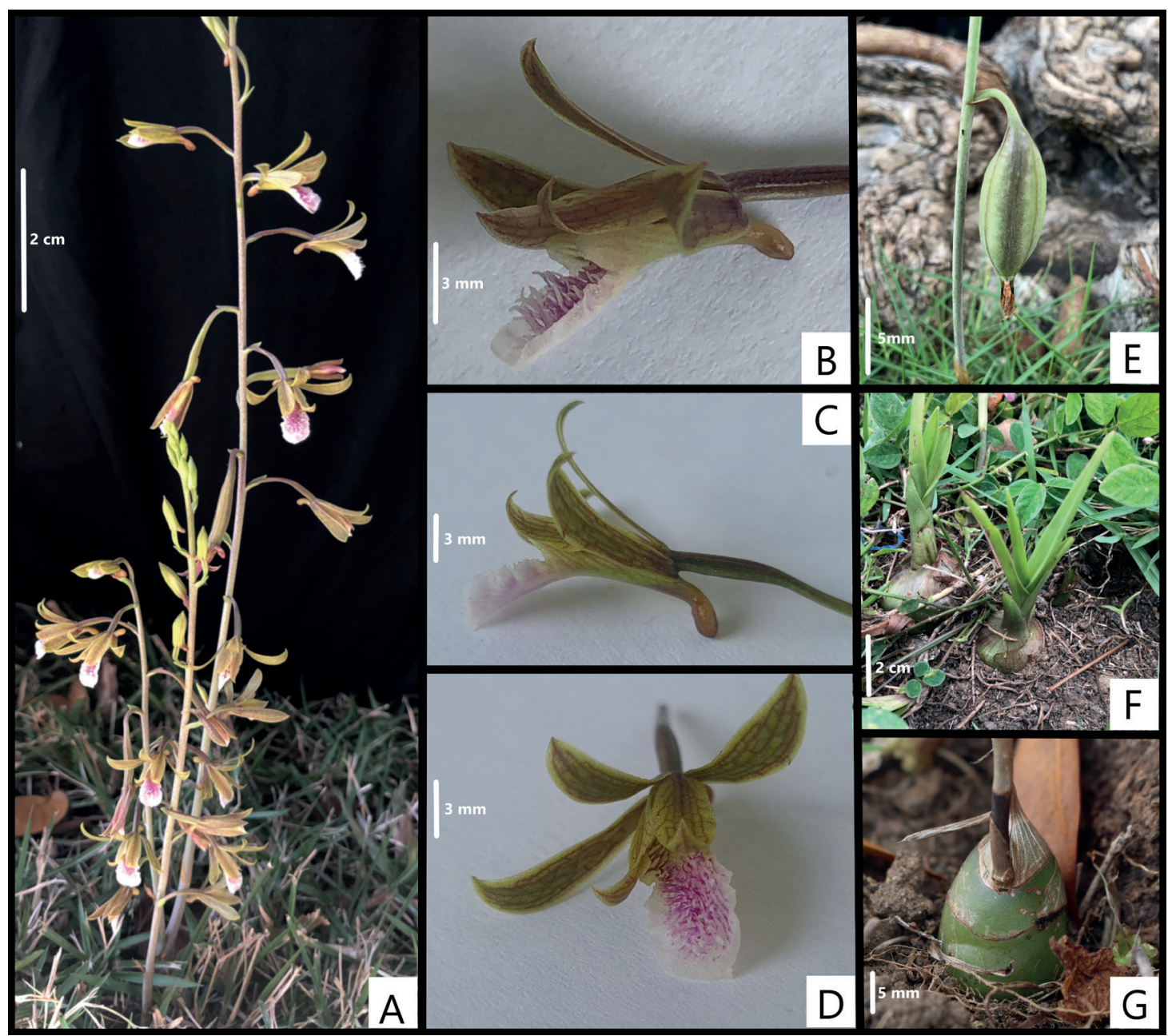

Figure 2. Eulophia graminea. A. Inflorescences. B. Flower, side view showing fleshy hairs on the mid lobe of the lip. C. Flower, side view, showing spur morphology. D. Flower, front view showing lip color patterns. E. Fruit. F. Pseudobulbs with leaves. G. Pseudobulb with base of an inflorescence. All photographs taken by James Ackerman and Normandie González from the University of Puerto Rico, Río Piedras population. Voucher: 16 Apr 2021, N. González-Orellana s.n. (UPRRP).

DESCRIPTION: The following is a description of Eulophia graminea based on material from Puerto Rico (Fig. 2 A-G).

Plants terrestrial, to $1 \mathrm{~m}$. Roots from base of pseudobulb. Stems pseudobulbous, ovoid to globose, sometimes compressed, composed of 3-5 internodes, $2.3-5.0 \mathrm{~cm}$ in diameter. Leaves $2-6$, distichous, enclosing the stem, blades conduplicate, linear, about $10 \mathrm{~cm}$ long, $10 \mathrm{~mm}$ wide, the first leaves are shorter. Inflorescences 1-2, lateral from the side of the pseudobulb, erect, 20-50 cm including peduncle; pedun- cle green to purple, glaucous, partially covered by 4-5 sheathing bracts; raceme few to many flowered, larger inflorescences sometimes sparsely branched panicle, floral bracts lanceolate, acuminate 4-9 mm long. Flowers resupinate; pedicellate ovaries 12-16 mm long; sepals and petals pale green, with maroon veins; dorsal sepal spreading, apically reflexed, oblanceolate, acuminate, $9-11 \mathrm{~mm}$ long $2.5 \mathrm{~mm}$ wide; lateral sepals similar, slightly asymmetrical $12 \mathrm{~mm}$ long, $2.5 \mathrm{~mm}$ wide; petals flanking the column, narrowly elliptic, acuminate, $8.5-10 \mathrm{~mm}$ long, 2.2-2.5 
$\mathrm{mm}$ wide; lip trilobed, and basally provided with a spur bent downwards, swollen toward apex, 2.5-3.5 $\mathrm{mm}$ long, lip 10-11 mm long, the lower $7 \mathrm{~mm}$ forming a tube with the column, 3 prominent ridges extend to the base of the mid lobe, these flanked by about 3 angling ridges on each side, lateral lobes ovate-oblong, rounded, $2 \mathrm{~mm}$ long from bottom of sinus, mid lobe white, oval, $6.5 \mathrm{~mm}$ long and $4.5-5 \mathrm{~mm}$ wide, disc suffused purple, densely provided with seven rows of purple fleshy hairs to $1.5 \mathrm{~mm}$ long fading to white toward apex of lobe, margins white to pale purple, crisped. Column clavate $4 \mathrm{~mm}$ long, column foot $1 \mathrm{~mm}$ long, anther hinged, pollinia 4 in unequal pairs. Fruit a pendent ellipsoid capsule 18-21 long, 7-8.5 mm diameter.
There are now three species of Eulophia in Puerto Rico and the West Indies (Ackerman 1995, Ackerman \& Collaborators 2014), one of which is native (E. alta (L.) Fawc. \& Rendle) and the other two are not, E. graminea and E. maculata. The latter species, commonly known as Oeceoclades maculata, has been recently reinstated as a Eulophia by Chase et al. (2021) based on interpretation of phylogenetic and morphological works by Martos et al. (2014) and Bone et al. (2015). Although Eulophia maculata has been resident in the Western Hemisphere at least since the early $19^{\text {th }}$ century, it is regarded as non-indigenous in the region and native to Africa and may have arrived in the ballast of slave ships (Stern 1988, Kolanowska 2013). The three can be distinguished by the following key:

\section{Key to the Species of Eulophia IN the West IndiES}

1. Leaves solitary from apex of pseudobulb, conspicuously mottled, leathery and persistent $\quad$ E. maculata 1a. Leaves 3 or more, concolorous, relatively thin, persistent or early deciduous

2. Pseudobulbs poorly developed or absent, leafy at flowering; lip saccate; petals form a hood over the column; sepals erect vertically; lip margin pinkish purple to burgundy; inflorescences $70-150 \mathrm{~cm}$ tall, racemose E. alta

2a. Pseudobulbs roughly globose, leafless at flowering; lip spurred; apices of sepals and petals spreading; lip margin white to pale purple; inflorescences generally are $<70 \mathrm{~cm}$ but can reach to $100 \mathrm{~cm}$, racemose or sometimes paniculate

E. graminea

AcKnOWLedGements. We thank José Lazaro Bocourt, Oscar Loyola Hernández, Ethan Freid, Michael Vincent, Tamara Heartsill, Steve Maldonado, Christian Torres, and Adolfo Rodríguez Velázquez for sharing their field observations of E. graminea. Betsaida Cabrera García checked for E. graminea collections at JBSD for which we are grateful. Support for NG-O was provided by the Puerto Rico Louis Stokes Alliance for Minority Participation Bridge to the Doctorate program (National Science Foundation HRD-1906130).

\section{Literature Cited}

Ackerman, J. D. (1995). An orchid flora of Puerto Rico and the Virgin Islands. Memoirs of the New York Botanical Garden, 73, 1-203.

Ackerman, J. D. (2007). Invasive orchids: weeds we hate to love? Lankesteriana, 7, 19-21.

Ackerman, J. D. (2017). Orchidées invasives: acceleration de la colonization et de la propagation. L'Orchidophile, 213, 167-173.

Ackerman, J. D. \& Collaborators. (2014). Orchid flora of the Greater Antilles. Memoirs of the New York Botanical Garden, 109, 1-625.
Ang, W. F., Lok, S. L., Chong, K. Y., Yeo, C. K., Ng, B. Y. Q., Ng, P. X., \& Tan, H. T. W. (2011). Eulophia R.Br. ex Lindl. (Orchidaceae) of Singapore. Nature Singapore, 4, 289-296.

Bone, R. E., Cribb, P. J. \& Buerki, S. (2015). Phylogenetics of Eulophiinae (Orchidaceae: Epidendroideae): evolutionary patterns and implications for generic delimitation. Botanical Journal of the Linnean Society, 179, 43-56.

Bonnardeaux, Y., Brundrett, M., Batty, A., Dixon, K., Koch, J., Sivasithamparam, K. (2007). Diversity of mycorrhizal fungi of terrestrial orchids: compatibility webs, brief encounters, lasting relationships, and alien invasions. Mycological Research, 111, 51-61.

Catling, P. M. (1980). Rain-assisted autogamy in Liparis loeselii (1.) L. C. Rich. (Orchidaceae). Bulletin of the Torrey Botanical Club, 107, 525-529.

Chang, C., Hu, W.-H., Chen, Y.-C., Su, Y.-K., \& Chiu Y. T. (2010). In vitro flowering and mating system of Eulophia graminea Lindl. Botanical Studies, 51, 357-362.

Chase, M. W., Schuiteman,A.\& Kumar,P. (2021). Expansion of the orchid genus Eulophia (Eulophiinae; Epidendroideae) to include Acrolophia, Cymbidiella, Eulophiella, Geodorum, Oeceoclades and Paralophia. Phytotaxa, 491, 47-56. 
Cohen, I. M. \& Ackerman, J. D. (2009). Oeceoclades maculata, an alien tropical orchid in a Caribbean rainforest. Annals of Botany, 104, 557-563.

Daehler, C. C. (2003). Performance comparisons of cooccurring native and alien invasive plants: implications for conservation and restoration. Annual Review of Ecology, Evolution and Systematics, 34, 183-211.

Dod, D.D.(1986). Oeceoclades maculata (Orquidaceae[sic]), 1975 a 1985 , en una marcha inexorable cruza La Isla Española. Moscosoa, 4, 203-205.

Falcón, W., Ackerman, J. D. \& Tremblay, R. L. (2017). Quantifying how acquired interactions with native and invasive insects influence population growth rates of a non-indigenous plant. Biological Invasions, 19, 895-911

Fan, X. L., Barrett, S. C. H., Lin, H., Chen L. L., Zhou, X. \& Gao, J. Y. (2012). Rain-triggered self-pollination provides reproductive assurance in a deceptive orchid. Annals of Botany, 110, 953-958.

Foster, E. \& Ackerman, J. D. (2021). Present and future distribution of two non-indigenous orchids and their acquired enemy in Puerto Rico. Biological Invasions, preprint. doi:10.1007/s10530-021-02596-3

García-González, A., Damon, A., Iturbide, F. A., OlaldePortugal, V. (2013) Reproduction of Oncidium poikilostalix (Orchidaceae), potentially invading coffee plantations in Soconusco, Chiapas, México. Plant Ecology and Evolution, 146, 1-9.

González-Díaz, N., \& Ackerman, J. D. (1988). Pollination, fruit set, and seed production in the orchid, Oeceoclades maculata. Lindleyana, 3, 150-155.

UF/IFAS. (2021). Eulophia graminea, Chinese crown orchid. Center for Aquatic and Invasive Plants (CAIP), Institute of Food and Agricultural Sciences, University of Florida. Retrieved from https://plants.ifas.ufl.edu/plant-directory/ eulophia-graminea/ (Accessed 10 Oct 2021).

Kolanowska, M. (2013). The naturalization status of African Spotted Orchid (Oeceoclades maculata) in Neotropics. Plant Biosystems, 148, 1049-2055.

Kolanowska, M. \& Konowalik, K. (2014). Niche conservatism and future changes in the potential area coverage of Arundina graminifolia, an invasive orchid species from Southeast Asia. Biotropica, 46, 157-165.

Larson, B. M. H. (2005). The war of the roses: demilitarizing invasion biology. Frontiers in Ecology and the Environment, 3, 495-500.

Macrae, C. (2002). New weed found in Darwin. Department of Business, Industry and Resource Development, Primary Industry and Fisheries, Northern Territory Government, Australia [Accessed by R. Pemberton 31 Jan 2008 in Pemberton 2013].

Martos, F., Johnson, S. D., Peter, C. I. \& Bytebier, B. (2014). A molecular phylogeny reveals paraphyly of the large genus Eulophia (Orchidaeae): a case for the reinstatement of Orthochilus. Taxon, 63, 9-23.

O’Conner, M., Govender, T. \& Jolliffe, K. (2006). Eulophia graminea - the ET orchid. Orchids South Africa, 37, 128-131.

Oppenheimer, H. L. (2006). New Hawaiian plant records for 2004. Bishop Museum Occasional Papers, 88, 10-15.Orchid Species (2021). Eulophia graminea Lindl. 1833 SECTION Eulophia. Retrieved from http://www.orchidspecies.com/eulgrminea.htm (Accessed 16 April 2021).

Orchid Species (2021). Eulophia graminea Lindl. 1833 SECTION Eulophia. Retrieved from http://www.orchidspecies.com/eulgrminea.htm [Accessed 16 April 2021]

Pemberton, R. W. (2013). Rapid geographic spread of the alien orchid Eulophia graminea in Florida. Selbyana, 31, 47-51.

Pemberton, R. W., Collins, T. M., \& Koptur, S. (2008). An Asian orchid, Eulophia graminea (Orchidaeae: Cymbidieae), naturalizes in Florida. Lankesteriana, 8, 5-14.

PIER. (2021). Pacific island ecosystems at risk, version 20180602 (posted online 02 June 2018). Retrieved from http://www.hear.org/pier/species/eulophia_graminea. htm (Accessed 19 April 2021).

Recart, W., Ackerman, J.D., \& Cuevas, A.A. (2013). There goes the neighborhood: apparent competition between invasive and native orchids mediated by a specialist florivorous weevil. Biological Invasions, 15, 283-293.

RStudio Team (2021). RStudio: Integrated Development Environment for R. RStudio, PBC, Boston, MA URL http://www.rstudio.com/.

Squirrell, J., Hollingsworth, P. M., Bateman, R. M., Dickson, J. H., Light, M. H. S., MacConaill, M. \& Tebbitt, M. C. (2001). Partitioning and diversity of nuclear and organelle markers in native and introduced populations of Epipactis helleborine (Orchidaceae). American Journal of Botany, 88, 1409-1418.

Stern, W. L. (1988). The long-distance dispersal of Oeceoclades maculata. American Orchid Society Bulletin, 57, 960-971.

Suetsugu, K. (2019). Rain-triggered self-pollination in $\mathrm{Li}$ paris kumokiri, an orchid that blooms during the rainy season. Ecology, 100, e02683.

Tremblay, R. L., Ackerman, J. D., Zimmerman, J. K. \& Calvo, R. N. (2005). Variation in sexual reproduction in orchids and its evolutionary consequences: a spasmodic journey to diversification. Biological Journal of the Linnean Society, 84, 1-54.

Wunderlin, R. P., Hansen, B. F., Franck, A. R. \& Essig, F. B. (2021). Atlas of Florida Plants (http://florida.plantatlas. usf.edu/). [S. M. Landry and K. N. Campbell (application development), USF Water Institute.] Institute for Systematic Botany, University of South Florida, Tampa. (Accessed 10 October 2021). 